Article

\title{
Governing Uncertainties in Sustainable Energy Transitions-Insights from Local Heat Supply in Switzerland
}

\author{
Basil Bornemann ${ }^{1, *}$, Stephan Schmidt ${ }^{1}$ and Susanne Schubert ${ }^{2}$ \\ ${ }^{1}$ Department of Social Sciences, University of Basel, 4051 Basel, Switzerland; E-Mails: basil.bornemann@unibas.ch (B.B.), \\ stephan.schmidt@unibas.ch (S.S.) \\ 2 Institute IWAR, Technische Universität Darmstadt, 64287 Darmstadt, Germany; E-Mail: susanne.schubert@uba.de \\ * Corresponding author
}

Submitted: 20 May 2016 | Accepted: 10 October 2016 | Published: 4 November 2016

\begin{abstract}
The governance of sustainable energy transitions (SET) is facing multiple technological, economic, societal and political uncertainties. In practice, these energy-related uncertainties play a role not only at the level of "major politics," but also in the policymaking of local decision makers and planners. This paper seeks to attain a more differentiated understanding of how uncertainties concerning the energy transition play out and are dealt with in policymaking and planning "on the ground." To do so, the paper combines conceptual reflections with an explorative empirical study on local heat supply policy in Switzerland. In conceptual regards, it proposes some distinctions of types of uncertainties related to energy transitions, and a typology of strategic decision options for dealing with uncertainty. On this basis, the paper reveals similarities and differences regarding the perception of uncertainties and ways of dealing with them in a number of Swiss cities. These insights evoke further questions about the causes and effects of different sensitivities to uncertainty and ways of dealing with them.
\end{abstract}

\section{Keywords}

energy transition; governance of uncertainty; sustainability; sustainability governance; uncertainty; urban heat supply

\section{Issue}

This article is part of the issue "Sustainable Planning and Technologies", edited by Hatem Ibrahim (Qatar University, Qatar), Ahmed Khan (Université Libre de Bruxelles, Belgium), Steffen Lehmann (University of Portsmouth, UK), Dellé Odeleye (Anglia Ruskin University, UK) and Atiq Zaman (Curtin University, Australia).

(C) 2016 by the authors; licensee Cogitatio (Lisbon, Portugal). This article is licensed under a Creative Commons Attribution 4.0 International License (CC BY).

\section{Introduction}

Energy systems all over the world are currently facing two major challenges. On the one hand, the existing infrastructures in many countries are reaching the end of their technical lifespans. On the other hand, the discourse about sustainable development (and its energyrelated storylines such as "peak-oil," "climate change," and "Fukushima") is questioning the effectiveness and legitimacy of the incumbent energy systems and has brought about political pressure to reform these systems (Araújo, 2014; Solomon \& Krishna, 2011). In light of these challenges, some countries have begun fostering sustainability-oriented transitions of their energy sys- tems. For this purpose, they have set up concerted governance efforts that cut across various policy domains and levels (Laes, Gorissen, \& Nevens, 2014). In Switzerland, for example, the federal government has come up with an overarching energy strategy, which includes goals such as the reduction of energy consumption, a further substitution of fossil fuels with renewable energy, and the reduction of $\mathrm{CO}_{2}$ emissions. While this strategy promotes a general national policy framework for the envisioned energy transition, the Swiss federalist system renders sub-national actors, such as cantons and municipalities, important players for the realization of the goals. In fact, these actors dispose of the main legislative and administrative competences in energy policy and plan- 
ning (see Schubert, 2015) and, therefore, have to deal with the concrete challenges that come with the energy transition and its governance "on the ground."

One of the main challenges related to the governance of sustainable energy transitions is uncertainty (Meadowcroft, 2009; Meijer \& Hekkert, 2007). Generally, such uncertainty results from both the long-termism and complexity of the endeavor. For example, energy infrastructure involves long-ranging investment cycles which deal with making projections up to 60 years in advance. Yet it remains uncertain which societal developments and technological innovations-not to mention what changes in political dynamics as well as individual behaviors - might take place within these time horizons (Monstadt, 2004). In addition, the envisioned transitions are highly complex in nature, as they refer to the entire energy chain (from production through distribution to consumption) and cut across various technological, economic, social, and ecological domains involving multiple actors at different levels. The various linkages among the different subsystems and levels virtually guarantee uncertainty.

These kinds of uncertainty are also relevant in the field of energy for heat demand. As heat constitutes a major component of residential energy demand (up to $80 \%$, including hot water, in northern European countries) and the integration in renewable energies slows (compared to the pace of their development in power supply during the last ten years), this field is assumed to bear a crucial potential for realizing a sustainable energy transition (e.g., BMWI \& BMU, 2010). At the same time, there is an urgent need to transform the urban infrastructure in light of ambitious political goals in energy and climate politics. As the planning related to urban heat supply takes place at the local level, where the existing infrastructure requires major investments for renovation and where political goals for integration of renewable energies into the heat supply have to be transformed into concrete measures, it is the local policymakers and planners who are facing uncertainties and have to deal with them in concrete decisions.

While decision-making in the face of uncertainty is probably most prominently discussed in the field of psychology with a focus on individual behavior (Tversky \& Kahneman, 1974), the topic is also a recurrent "classic" in various fields of research focusing on collective decisionmaking-ranging from organization and management studies (Courtney, Kirkland, \& Viguerie, 1997; Weick \& Sutcliffe, 2015) to policy research (Arentsen, Bressers, \& O'Toole, 2000; Renn, 2008). More recently, the issue has gained prominence in the interdisciplinary field of environmental and sustainability studies, reflecting a core challenge of sustainability governance (Berkes, 2007; Grunwald, 2007; Polasky, Carpenter, Folke, \& Keeler, 2011). Some accounts even refer to uncertainty as a core element of a more general problematic that modern (reflexive) governance has to deal with (Beck, 2006; Voss, Newig, Kastens, Monstadt, \& Nölting, 2007).

These governance-oriented literatures have pro- vided valuable conceptual and empirical insights into the types of uncertainties and strategies of dealing with them in terms of collective action. However, we see two important knowledge gaps. First, there is little conceptual and empirical knowledge regarding the concrete meanings and manifestations of uncertainty in specific practice fields such as energy transitions. Second, existing research tends to focus on rather aggregate arrangements for dealing with uncertainty on a strategic level of collective choice. Yet, there is only little knowledge about how uncertainty is perceived and dealt with by actors on a more operational and individual level of decisionmaking on the ground.

With our paper, we seek to address these knowledge gaps and shed light on variations of uncertainty and ways of dealing with them in the particular policy field of local heat supply in Switzerland. To do so we ask the following question: How are uncertainties perceived and dealt with in local heat policymaking and planning in Switzerland? Following this question, we aim to contribute conceptual and empirical insights to the study of uncertainties in energy transitions as well as uncertainty-oriented governance and policymaking more generally. In conceptual respects, we bring together the general notion of uncertainty with the complexity of energy transitions proposing a nuanced understanding of energy transition-related uncertainties. Furthermore, we provide a typology of basic strategic decision options for dealing with uncertainties, which can guide further governance-oriented uncertainty research. In empirical respects, we explore how uncertainties are perceived and dealt with in the context of different governance arrangements. These conceptual and explorative empirical insights shall provide the ground for further systematic inquiries on the relationship between uncertainty and policymaking.

We begin by outlining a conceptual understanding of uncertainty that takes account of the complexities of sustainability-oriented energy transitions (Section 2). After critically reflecting on an established distinction of three "classical" uncertainty-related governance strategies, we propose a generic typology that captures options for dealing with uncertainty on the ground (Section 3). We illustrate our conceptual propositions with empirical observations regarding the perception of energyrelated uncertainties and the strategies for dealing with these uncertainties in policymaking in three Swiss cities (Section 4). In the concluding Section 5, we summarize the results and discuss their implications for research and practice regarding the governance of energy-related uncertainties on the ground.

\section{Uncertainty in the Context of Sustainable Energy Transitions}

\subsection{Conceptualizing Uncertainty}

Uncertainty is a much-debated term that scholars from different disciplines define and delineate from other con- 
cepts, such as risk, ambiguity or ambivalence, in different ways (Gross, 2010, p. 53ff.; Jeschke, Jakobs, \& Dröge, 2013; Smithson, 1989, 2008; van Asselt \& Rotmans, 2002). According to a prominent definition by Walker et al. (2003, p. 5), uncertainty refers to "any deviation from the unachievable ideal of completely deterministic knowledge of the relevant system." As this definition suggests that basically all situations are characterized by uncertainty, its inclusivity comes at the expense of its clarity. Other definitions allow for more differentiation. Gross (2007), for example, locates uncertainty between two ideal typical situations: certainty on the one hand and the unknown on the other. While "certainty" implies that there is only one possible consequence of an action, a situation in which we do not know about the consequences of an action at all can be qualified as "unknown." Uncertainty refers to all situations with multiple possible consequences of one action which are only partly known (Gross, 2010, p. 3). ${ }^{1}$ Below the level of definition and delineation, the literature provides us with different typologies of uncertainty stemming from different disciplines and referring to different (more or less specific) contexts of application (Enserink, Kwakkel, \& Veenman, 2013; Grunwald, 2007; Milliken, 1987; Smithson, 2008).

First, cutting across the current literature, there are different understandings of the object of uncertainty, i.e. answers to the question of what exactly is uncertain. Various authors distinguish between ontic and epistemic uncertainties (van Asselt \& Rotmans, 2002; Walker et al., 2003). Ontic uncertainty refers to given contingencies and variabilities in the behavior of real world systems (nature, human behavior, society, technology). In contrast, epistemic uncertainty refers to some incomplete or limited knowledge about a certain situation. This means that our propositions and beliefs are uncertain. In the realm of epistemic uncertainty, one can further distinguish between factual and normative uncertainties. For example, Christensen (1985) distinguishes between the (un-)certainty of normative goals and instrumental means in decision situations; Mazouz (2003) explicitly points to the uncertainty of normativity. However, most frequently, epistemic uncertainty relates to some form of factual knowledge (Grunwald, 2007; Smithson, 2008; Voss et al., 2007). And we see good reasons to follow that line, since there are other concepts that denote contingent normativity (such as "ambivalence").

Below the distinction between ontic and epistemic uncertainty, there are several more specific suggestions to differentiate objects (and sometimes also locations) of uncertainty. In the context of integrated assessment and modelling, for example, van Asselt and Rotmans (2002) distinguish between states, processes, functions, outcomes, and impacts of uncertainty. In the context of organizational action, Milliken (1987) differentiates between state, effect, and response uncertainty.

A second fundamental dimension of uncertainty refers to the mode of uncertainty, that is, how or in what respect something is (regarded to be) uncertain. According to a common understanding, there are different levels of (epistemic) uncertainty. Some authors distinguish between non-fundamental uncertainty (as a lack of knowable knowledge) and fundamental uncertainty (as a lack of unknowable knowledge). Other authors suggest more differentiated conceptualizations that cover various interim steps such as inexactness, lacking measurements, immeasurability, conflicting evidence, reducible ignorance, indeterminacy, and irreducible ignorance (van Asselt \& Rotmans, 2002). In whatever form, the levels and types of uncertainty express the assumption that some situations are essentially uncertain due to fundamental problems in discerning knowledge about the quality or extent of an incident. In contrast, situations of non-fundamental uncertainty are in principle describable by probabilistic statements: if there was enough knowledge, they could turn into calculable risks or even certainty (in case of deterministic relationships).

A further analytical differentiation regarding the mode of uncertainty refers to its contestation. Uncertainties can be agreed on by the actors who are involved in a decision situation, or they can be contested (Gottschick, 2014). Whether at all or to what extent a situation is seen as certain or uncertain can become part of a dispute. Some can hold the knowledge that constitutes the understanding of a situation as certain while others doubt about it. These differences regarding the perception of uncertainty may have different causes, such as different "ways of knowing" or framings (Brugnach, Dewulf, PahlWostl, \& Taillieu, 2008). This understanding promotes a notion of (epistemic) uncertainty, which is essentially subjective and constructed.

We follow this manner of reasoning and regard uncertainty as a concept that organizes an actor's interpretation of a situation (Brugnach et al., 2008; Enserink et al., 2013; Smithson, 2008). However, for analytical purposes, we suggest maintaining the distinction between objective and subjective uncertainty (Milliken, 1987; Renn, 2008). Referring to objective uncertainties does not imply that these uncertainties are "objectively" true (i.e., ontic uncertainties). Rather, objective uncertainties denote situations in which actors are confronted with assertions and diagnoses of uncertainty (e.g., in the public or scientific discourse) that have not (yet) entered their individual action space. Accordingly, subjective uncertainties are interpreted objective uncertainties: uncertainties that have been perceived as being relevant by a cer-

\footnotetext{
${ }^{1}$ This definition is helpful to clarify the relationship between uncertainty and risks-two terms which are very often used in confusing ways. Following the classical understanding (quality of an incident multiplied by the probability of its occurrence), risks can be seen as representing a specific kind of "known" uncertainty, that is, an uncertainty, which is calculable with regard to the quality and the probability of a certain incident (mostly conceptualized in terms of "damage") (see Gross, 2010, p. 60ff.; Renn, 2008). In contrast, uncertainties proper are characterized by the lack of knowledge with regard to one of the two dimensions of risks, while a third category, the "unknown" (non-knowledge), refers to a situation where neither the probability nor the extent of an incident is known.
} 
tain actor. They have become a subjectively relevant reference point for his or her actions.

\subsection{Specifying Uncertainty for SET}

In light of these general conceptual considerations, how can we make sense of uncertainty in relation to sustainability-oriented energy transitions? More specifically, what uncertainties arise from the endeavour of transforming energy systems toward more sustainable ones? Traditionally, energy systems have been conceptualized in terms of technological infrastructures mediating between supply and demand. More recently, scholars have strived for more comprehensive analytical representations of the energy systems taking account of further societal dimensions of energy production, distribution, and use (Guy \& Shove, 2000; Monstadt, 2009; Schippl, Grunwald, \& Renn, 2012). This expansion of perspective toward socio-technical energy systems is of particular relevance for studying sustainability-oriented energy transitions (Everett, Boyle, Peake, \& Ramage, 2012; Kern \& Smith, 2008; Meadowcroft, 2009). And it has major consequences for thinking about uncertainties related to energy transitions.

A socio-technical system perspective implies that the physical components of energy systems (such as power plants, grids, steering devices and storage, etc.) are intertwined with institutions and networks of actors who shape technology through social interactions and practices. The technological domain defines a corridor for human action which creates opportunities as well as restrictions for innovation and change (see e.g. Raven, 2007; Verbong \& Geels, 2007). Monstadt (2009) emphasizes that technological infrastructures are both society-shaping and shaped by society. It is human actors-providers, users, and regulators-who construct, manage, and change technical artifacts and coordinate the provision of infrastructure services. From a sociotechnical system perspective, energy systems are characterized by specific knowledge, skills, norms, a deep formal organization, and a highly integrated and interconnected structure (Araújo, 2014; Goldthau, 2014). Changing this system means having to reconfigure infrastructures and services and to overcome established actor constellations, norms, values, and power relations (Kuzemko, Lockwood, Mitchell, \& Hoggett, 2016; Stirling, 2014).

Based on such a general understanding of complex socio-technical energy systems, uncertainties in relation to sustainable energy transitions have multiple sources that can be located in various technological, economic, societal, and political spheres of the system and the interplay of these spheres (Meijer \& Hekkert, 2007).

- Uncertainties in the technological sphere relate to the development and application of technologies for extracting and producing, distributing, and using energy resources as well as the future availability of these resources. Technological uncer- tainty refers to, but is not limited to, aspects such as future developments in combustion and transformation technology, the appropriate degree of (de)centralization of the energy system, the availability of future storage, and regulation technologies. Furthermore, it extends to future energy availability and the feasibility of exploring and exploiting new technologies like deep geothermal energy or fuel cell power (Akademien der Wissenschaften Schweiz, 2012);

- The costs and benefits of envisioned transition pathways and individual decisions regarding these pathways are at the core of uncertainty in the economic sphere. Usually these economic uncertainties stem from dynamic technological and market developments on both the supply and demand side. For example, there is uncertainty related to the strategic dynamics between competing energy providers. Moreover, related to cultural change and political dynamics, there are uncertainties regarding the development of energy demand;

- The societal sphere of SET-induced uncertainty includes and goes far beyond questions of social protest and public acceptance related to the innovation and development of new technologies and infrastructures. It extends to the manifold actors connected to the system, whether governing, regulating, or being directly affected by such a system. Hence, the interplay as well as the development of interests and practices of these multiple actors are relevant sources of uncertainty. For example, it is impossible to definitively predict how values and norms will change in the future, which lifestyles are or will be commonly shared, or how societal developments will influence consumption patterns. All this leads to high uncertainty regarding future behaviors and actions of individual and collective societal actors;

- Political uncertainties regarding the energy system and sustainable energy transitions relate to all kinds of collective decision-making and implementation processes that affect public discourses and policy frameworks, which, in turn, impact private decisions of companies or consumers. Corporate decision makers, for example, regularly point to the need for certain, if not stable, policy frameworks in order to be able to assess the risks and opportunities of investments in new technologies, etc. (Meijer \& Hekkert, 2007). In modern democratic societies, political uncertainties stem from open political competition among parties and interest groups. To a certain extent, political struggles are channeled by political institutions and defined procedures. However, in an ever-globalizing and increasingly complicated world (Willke, 2014), these political institutions might themselves become fluid, less reliable, and less important compared to more dynamic political discourses (Hajer, 2003). 


\section{Governing Uncertainty}

\subsection{Three Governance Strategies for Dealing with Uncertainty}

Strategies for dealing with uncertainty have been widely examined by different strands of governance-oriented literature with a policy and implementation (Arentsen et al., 2000; Bressers, 1997; Jänicke \& Jörgens, 1999; Morgan, Henrion, \& Small, 1990), organizational (Milliken, 1987), or planning focus (Christensen, 1985). Within these diverse literatures, three ideal typical approaches for dealing with uncertainty can be identified.

The traditional approach for dealing with uncertainty is through planning. In fact, uncertainty is one of the main reasons for planning and the emergence of planning theory (Camhis, 1979; Christensen, 1985). From a planning perspective, uncertainty is something that can be overcome by means of rational calculation and by "sorting things out" (Arentsen et al., 2000). More specifically, a plan can be regarded as a tool for substituting uncertainty with a promise of certainty in two ways. First, efforts can be made to fill existing knowledge gaps regarding the present and the future; second, this informational basis can be used to define goals and means that guide future actions and thereby bridge remaining uncertainties. Planning is about influencing the future (and its uncertainty) by means of decisions that rely on a comprehensive informational basis. This idea of planning has been criticized from many sides, both by those who are skeptical about the possibility of processing comprehensive information and by those who regard fixed goals and means as inappropriate for dealing with dynamic environments and reacting to emerging surprises that result from uncertainties (Meadowcroft, 1999).

Given the shortcomings of the classical planning paradigm, an alternative model of incrementalism has been suggested that rests on step-by-step decisions and actions that take account of the information that is available at a certain point in time (Braybrooke \& Lindblom, 1963; Lindblom, 1969, 1973, 1999). Decisions are rather short-term, made in the light of available means and information. They refer to the terrain that can in fact be overseen at a certain point in time from a certain point of view. This incremental approach to decision-making ensures that the information basis is constantly being extended as the decision process evolves. It rests on an experimental trial-and-error logic that allows for cautious and stepwise exploration of uncharted terrain. Incrementalist approaches have not only been celebrated for their empirical adequacy, but also for their normative strength in dealing with complex issues. However, they are also criticized for being biased to conservative positions as they promote a vested interest in the status quo and hinder the kind of fundamental change advocated by sustainability proponents (see Meadowcroft, 1999).
With regard to the shortcomings of both planning and incrementalism, a third way is supposed to integrate the strength of both approaches and, at the same time, avoid their shortcomings. This third way has been called "directed incrementalism" (Grunwald, 2000; Kemp \& Loorbach, 2006; Steurer \& Martinuzzi, 2005). At the core of this approach are flexible strategies rather than fixed plans. These strategies are supposed to be constantly adapted to dynamically changing conditions without neglecting overall visions. From the perspective of directed incrementalism, policymaking is thus about maneuvering through a dynamic landscape towards an overall goal. Within an approach of directed incrementalism, uncertainties are not controlled once and for all; rather, uncertainties are constantly reduced through continuous learning and the adaptation of an overall strategy.

These three ideal types provide important theoretical insights and illuminate empirical forms of dealing with uncertainty. However, when it comes to understanding how policymakers on the ground deal with uncertainty, at least two limitations become visible. First, the three types refer to patterns of meso-level (i.e., organizational) action courses; however, they do not capture uncertainty-related actions by individual actors within these organizations. Second, these overall strategies come with normative-prescriptive implications of how to adequately and effectively deal with uncertainty, rather than analytically capturing how uncertainties are actually dealt with.

\subsection{Dealing with Uncertainty "On The Ground": A Typology of Strategic Options}

In what follows, we provide a complementary conceptual framework for understanding how uncertainties are dealt with in policymaking and planning. Compared to the rather general and aggregate (meso-)strategies that become manifest at an organizational level, this framework is supposed to capture, in a more differentiated way, how uncertainties are dealt with at the micro-level of individual actions and practices (Moore, 2008). We assume that individual policymakers can choose from a "menu" of ideal typical strategic options for dealing with uncertainties. This menu is represented in our framework. We have developed it through a method of literature-informed rational imagination (Byrne, 2005) from the perspective of policymakers. This process was guided by the following question: How would rational policymakers deal with some form of objectively given uncertainty? ${ }^{2}$

By imagining strategic action options from the perspective of rational policymakers, we depart from other approaches that seek to identify strategies for managing uncertainties from the perspective of different scientific disciplines (Bammer, Smithson, \& Goolabri Group, 2008). However, our efforts do not start from scratch, but take

\footnotetext{
2 This implies that we do not engage with all kinds of imaginable uncertainty-related actions, such as actions to create, impose, or foster uncertainty (Smithson, 2008). Rather, we are interested in ways of dealing with some form of objectively given uncertainty.
} 
account of the rich literature pertaining to strategies of dealing with uncertainty (such as the rich material in Bammer \& Smithson, 2008; Polasky et al., 2011; Weick \& Sutcliffe, 2015). Therefore, what we did was reconstructing and sorting the strategies mentioned in the literature along a process of rational imagination from the perspective of allegedly rational administrative actors.

Referring to rationality neither implies that the identified options would necessarily entail rational results, nor does it mean that actors do in fact rationally choose these options. Rather, it reflects our assumption that actors are interested in overcoming the objective uncertainties they are confronted with in ways, which they can present as being rational. More specifically, we assume that actors, in particular in an administrative context, feel urged to frame their actions in terms of rationality, that is, they present themselves as if they acted in a rational way (Gross, 2010; Schimank, 2005).

The strategic options captured in the framework do not represent fully developed strategies. Rather, they take the form of basic "strategic postures" describing the "intent" or basic rationale, "but not the actions required to fulfill that intent" (Courtney et al., 1997, p. 74). The framework takes the form of a binary decision tree: At each level of decision there are two alternative options which are related to a certain rationale.

In the following, we describe the framework along the different strategic action options. While Figure 1 provides an overview of the basic structure of the framework, Table 1 illustrates the rationales behind the different strategy options:

(1) At the most fundamental level, actors are confronted with some form of objective uncertainty (e.g., in the form of uncertainty claims made by other actors, such as scientific studies), and have the choice between two alternative approaches for dealing with it. Acknowledging uncertainty means that actors translate objective uncertainty into subjective uncertainty, i.e., a form of uncertainty that becomes relevant for their own perception of an action situation. This translation implies that actors become aware of uncertainty and decide to deal with it in one or the other way in their further actions. Neglecting uncertainty implies that objective uncertainty does not translate into a subjectively perceived challenge. For whatever reasons, actors turn a blind eye on uncertainty and do not take account of it in their subjective perception of an action situation. Accordingly, uncertainty is neither taken into consideration in further decisions and actions, nor is it seen as something that would require further action.

(2) As soon as uncertainty is acknowledged as a subjectively relevant challenge, there are two basic options for dealing with it. First, actors can decide to actively engage with uncertainty or to passively cope with it. A strategy of active uncertainty management implies that an actor perceives uncertainty as relevant challenge that he/she should actively engage with in one or the other way. In contrast, a strategy of passive coping means that uncertainty, though acknowledged as subjectively relevant, is regarded as a challenge that cannot or should not be treated actively by the actor him-/herself. This consideration could be based on the impression (or assertion) that an active uncertainty management would overwhelm an actor's own capacity, that it lies beyond his/her institutionally legitimized action realm, or that it produces outcomes which worsen the situation.

(3) A strategy of passive coping can be further distinguished by two more specific options. First, actors who are unable or unwilling to actively manage uncertainties by themselves might decide to shift the responsibility for dealing with the uncertainty to

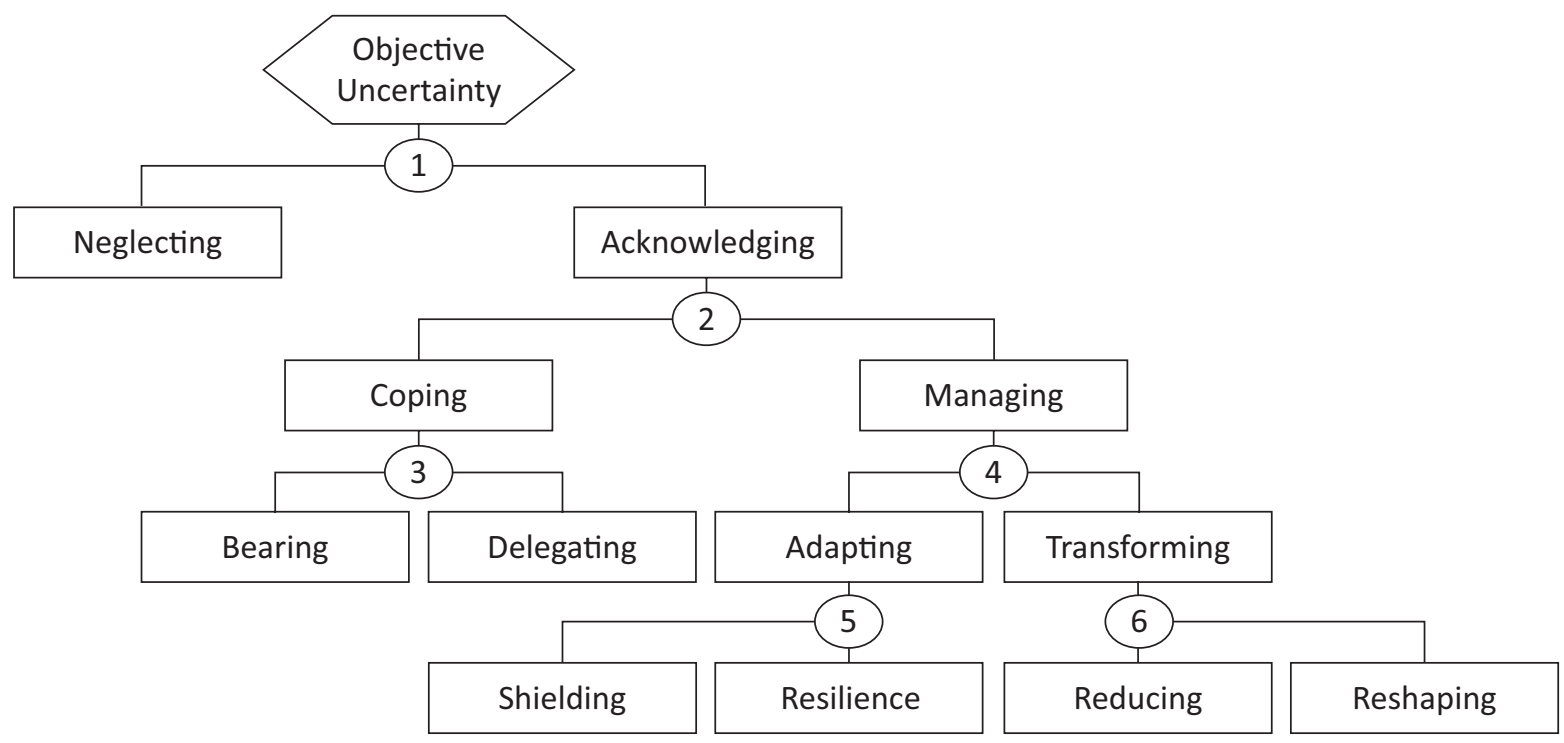

Figure 1. Overview of strategic options for dealing with uncertainty. 
Table 1. Strategic options and related rationales.

\begin{tabular}{ll}
\hline Strategy & Rationale \\
\hline $\begin{array}{l}\text { Neglecting } \\
\text { Acknowledging }\end{array}$ & We do not believe that there is uncertainty at all. \\
Managing & We know that there is uncertainty, and we have to actively engage with it. \\
Coping & We know that there is uncertainty, but we cannot do anything about it. \\
Bearing & We know that there is uncertainty, but we have to live with it. \\
Delegating & We know that there is uncertainty, but somebody else should deal with it. \\
Adapting & We know that there is uncertainty, and we can actively face it by developing our own capabilities. \\
Transforming & We know that there is uncertainty, and we can actively engage with it by transforming it. \\
Shielding & We know that there is uncertainty, and we can actively protect ourselves against its potential effects. \\
Resilience & We know that there is uncertainty, and we can actively prepare ourselves against its potential effects. \\
Reducing & We know that there is uncertainty, and we can actively reduce it by producing more knowledge. \\
Reshaping & We know that there is uncertainty, and we can actively influence it. \\
\hline
\end{tabular}

other actors. This delegation strategy builds on the assumption (or assertion) that other actors are better prepared, that is, more capable, eligible, or entitled, to deal with an uncertainty at hand. A second option for passively coping with uncertainties, which are regarded relevant, but appear to lie outside an actor's action realm consists in accepting them. From a rational point of view, this bearing strategy builds on the idea that uncertainty cannot, at least for the time being, be dealt with by any actor at all: it is a "given" reality that one has to live with in a "wait and see" manner.

(4) Strategies to actively manage uncertainty can take on two forms, which can be distinguished with regard to the object of management. An adaptation strategy addresses the actor him-/herself as the object of management and involves actions of selfmanagement. Based on whatever considerations, an actor comes to the conclusion that it is not the uncertainty itself to be managed (since it, for example, might lie beyond the realm that can be effectively steered by the actor); it is rather the actor him-/herself who is in need of management in order to deal with uncertainty in a rational way. In contrast to this strategy of active self-management by adaptation, a transformation strategy builds on the assumption the uncertainty itself can and should become the object of management. Rather than adapting oneself toward uncertainty, the actor regards actions directed at changing the uncertain situation to be more promising and suitable to deal with a given uncertainty.

(5) Strategies to actively manage uncertainties in a mode of self-adaptation ideally take two different forms. A first option of adaptive uncertainty management is to adopt a shielding strategy that protects against a given uncertainty and its potential consequences by establishing protective means (such as insurances). A second option for dealing with uncertainties in a self-managing way is to build up capacities that allow for reacting to uncertainties as soon as their consequences become real. This resilience strategy includes the development and maintenance of open and responsive structures, that is, the improvement of buffer capacities by assigning resources for dealing with future events (Kaufmann \& Blum, 2012; Longstaff, 2012).

(6) An actor who decides to actively transform a given uncertainty has two further options to do so. First, following a reduction strategy implies that actors foster the production or acquisition of new knowledge in order to fill the knowledge gap that makes up for the uncertainty. This strategy presupposes that uncertainties are conceived of as a lack of knowledge and thus can be eliminated or alleviated by more or different knowledge and increased diagnostic and prognostic capacities, for example, by involving experts. An alternative to this reduction strategy is to take actions that are directed at the situation which is regarded as uncertain. These reshaping strategies can be either of a symbolic nature (i.e., reshaping uncertainties by reframing or retelling them) or of a substantial nature (i.e., changing a situation that is perceived as uncertain in terms of material reconfiguration).

\section{Uncertainty "On The Ground": Local Heat Policies in Switzerland}

\subsection{Approach and Methods}

To find out about perceptions of energy-related uncertainties and ways of dealing with them, we conducted a qualitative study on local heat supply policymaking and planning in Switzerland. The study was not designed to generate systematic generalizable (or even explanatory) knowledge; rather it aimed at illustrating our conceptual considerations with empirical forms. In a first step, we analyzed 16 energy plans and energy concepts of Swiss towns to reveal how uncertainties are considered and treated in these official plans. Second, three in-depth 
case studies-Basel, Berne and Winterthur-were carried out to learn how the uncertainties are perceived and dealt with on the ground by local policymakers and planners. These case studies draw on data from qualitative expert interviews with employees of the administration, urban planners, and municipal energy providers (see "Empirical Data" in the Annex). Aside from the specific issue of uncertainty, the interviews covered multiple aspects of local energy planning practice, such as institutional conditions, coordination procedures, and planning instruments (see Schubert, 2015). We analyzed the interview transcripts by looking more closely at passages that referred to uncertainty and their treatment in policy and planning practice. Based on our two conceptual schemes-types of energy-related uncertainties on the one hand, and strategic options for dealing with uncertainties on the other-we interpreted the relevant passages to identify empirical correlates to our concepts. We discussed and further condensed our observations in a step-by-step manner accompanied by group discussions among the authors.

The three cases for in-depth analysis were selected based on their specific combination of similarities and differences. First, all three cases expose similar longterm time horizons of their energy policy rendering uncertainty a potentially important topic. ${ }^{3}$ Furthermore, the cases are similar regarding two basic organizational matters: While the overall responsibility for energy policy and planning lies with the energy department of the municipality or, in the case of Basel, with the canton, the local energy supply companies are public-law companies in municipal or cantonal ownership.

Second, the cases differ regarding their overall governance arrangements in energy planning (for details see Schubert, 2015). In fact, each of the three cases approximates one particular (meso-level) governance strategy for dealing with uncertainty (see 3.1). In Berne, energy planning follows a rather holistic approach and is established in a comprehensive and cross-cutting governance arrangement of spatial planning ("Richtplanung"). The city of Basel can be regarded as representing an incremental approach, renouncing an overall planning scheme for future urban heat supply. In Winterthur, energy planning is mainly organized in a sectoral manner with some interfaces to overall spatial planning; therefore, it represents a middle way between the holistic arrangement of Berne and Basel's incrementalist approach.

Since these governance schemes can be regarded as "typical" in the sense that they can be expected to occur in multiple different contexts, the case selection paves the way for some modest generalization of the empirical insights beyond local heat policy in Switzerland. At least, the selection of three cases with different governance schemes allows for reflections on the nexus between in- dividual strategies to deal with uncertainties and overall governance arrangements (4.3). Before we come to that particular point, however, we focus on the two basic questions, how uncertainties are reflected in planning documents and perceived by actors (4.1) and how they are dealt with (4.2).

\subsection{How is Uncertainty Reflected?}

Our empirical analysis reveals that uncertainty is a constant and relevant topic in local policymaking and planning for future heat supply. Yet, there are important qualifications to be made. First, within the analyzed official energy planning documents of 16 Swiss cities, uncertainty does not play a very prominent role. Some documents do not explicitly mention the term uncertainty (e.g., Geneva; Schlieren; La Brillaz; Bulle). Rather, uncertainty is an implicit topic that shines through the efforts made in data collection about demand and heat potentials, prognosis, and finally defined strategies, which reflect gaps of knowledge and missing forecasting reliability. Nevertheless, in some of the analyzed planning documents, uncertainty is explicitly mentioned as a relevant factor and occurs in different ways which reflect the above mentioned SET-induced types of uncertainty. The availability of energy resources is the most obvious source of uncertainty in energy planning, referring to such aspects as the usable heat potential from drinking water, the amount of economically usable geothermal energy, the prospective potential of synthetic natural gas, and the usable amount of wood for heat purposes, not at least due to its dependence on developments and decisions in other policy fields, especially landscape management (e.g. Arlesheim; Berne; Thun). The availability of industrial waste heat is further mentioned as an uncertain energy source, since it depends on continuance in industrial processes and the long-term existence of industrial waste heat suppliers in the specific location (e.g., Boedeli). The availability of resources relates to the economic as well as the technological sphere of uncertainty, since the economic viability of extraction or production technologies is crucial in this context. However, the political sphere also plays a part, since the politically defined legal framework conditions set guidelines for the use of available resources. Some planning documents (e.g., Aarau; Kloten) seem to refer to societal uncertainties, for example, when reflecting on the development of heat demand for residential as well as industrial use, and thereby take account of changing consumption behaviors.

In contrast to the official planning documents, the interviewed actors involved in planning processes and decision-making for local heat systems refer to uncertainty more explicitly and in more diverse and nuanced ways. First of all, technological development and especially viability thresholds of (new) technologies for heat

\footnotetext{
${ }^{3}$ The energy plan of Berne targets the year 2035 (Stadt Bern, 2012, p. 4). Winterthur adopts the same time horizon (Stadt Winterthur 2011), but has an additional underlying energy concept with target values for 2050 (Stadt Winterthur, Umwelt- und Gesundheitsschutz, 2011). The energy concept of Basel refers to the year 2050 (Kanton Basel-Stadt, 2013, p. 8).
} 
supply are frequently named as relevant uncertainties, e.g., in cases of fuel cells, geothermal energy, and energy storage technology. The viability threshold of these technologies is not regarded as stable, but rather it is seen as depending on the users' acceptance and willingness to pay. How users - primarily private homeowners-will respond to new technologies and what they will be willing to invest is also named as an uncertain dimension (IP 1, 2 and 3 ).

With regard to diverse technologies for heat supply, interdependencies between different energy related sectors are also mentioned as a crucial source of uncertainty (IP 1 and 4). How will electricity production from renewables develop in general, and how about heating technologies that depend on electrical energy (such as heat pumps)? How will this affect the electricity rate in the heating sector? How will electro mobility develop and impact the demand for power, including its consequences for cheap power available for heating purposes? Further, the uncertain development of demand for cooling appliances, depending on future comfort demands, is mentioned as a source of uncertainty regarding the societal sphere and changing consumption patterns (IP 4, 5 and $6)$. Reflecting on these interdependencies inside the energy sector, actors pay attention to the high complexity arising from dynamic developments which generate uncertainty in their concrete decision-making processes. The political sphere of uncertainty is described by the experts in terms of changing political priorities relating to environmental problem awareness and interest, e.g., increasing awareness of environmental and health problems from fine dust created by wood combustion (IP 1 and 4)-all of them coming along with possible changes in legal framework conditions.

Overall, uncertainty is referred to in various sources in the context of policymaking and planning for future urban heat supply. While planning documents on the one hand mention uncertainties only marginally and mostly implicitly, focusing on technological and economic uncertainties, the interviewed experts seem to reflect on uncertainties in a more differentiated and complex way also considering political and societal sources of uncertainty.

\subsection{How Is Uncertainty Dealt with?}

According to our analysis, local policymakers in Swiss towns adopt a variety of strategies to deal with energyrelated uncertainties occurring throughout the planning and policymaking process. These strategies can be interpreted as approximations to the ideal typical strategic postures we have introduced above. While some strategies play a role with regard to all governance arrangements, i.e. holistic planning, incrementalism, and directed incrementalism, other strategies can be observed only in relation to particular arrangements.

The most obvious approach for dealing with uncertainties involves simply neglecting them, i.e., not including objective uncertainties into the subjective action realm. Many uncertainties that are arguably relevant for future heat supply systems and are regularly referred to in the scientific debate, such as uncertainties resulting from shrinking demands due to renovation of the building stock, the development status of technology, and changing and competing political priorities (DENA, 2010; DLR, IWES, \& IFNE, 2012; UBA, 2007; Wuppertal Institut für Klima, Umwelt, Energie, 2010) are not reflected or even named in the analyzed energy planning documents.

Another strategy of passively coping with uncertainties consists of accepting once acknowledged uncertainties but leaving them respectively untouched and unaddressed in the course of planning and decision-making. Such a strategy of bearing-or in practice "wait and see"-becomes evident when uncertainties are mentioned in planning documents but are not addressed by further actions. In the case of Aarau, for example, some sources of uncertainties (e.g., energy consumption patterns) which had been acknowledged in the process of setting up energy plans were not mentioned in argumentation for the final decisions for heat supply (Stadt Aarau, 2012). This strategy seems to result from both established energy policy and the pressure from higher administrative levels that force municipalities to actually act and transform their local infrastructure with an awareness of its long lifespan and the high costs of investing in it.

A different way of dealing with uncertainties arising from the complex interplay between heat sources and transformation technologies is the reference to overarching policy goals, such as cantonal orders concerning the application of energy sources, as named in the energy plans of Berne and Wädenswil for example (Stadt Bern, 2012; Stadt Wädenswil, 2009). Such a strategy comes with a simplification of the interdependencies in energy supply and doesn't consider local characteristics in the existing infrastructure or patterns of demand. This reference to cantonal priority lists for the application of heat sources without analyzing their implications and usefulness for the local situation can be considered a strategy of passive coping in the form of delegation of responsibility.

An important strategy for actively dealing with uncertainty in all governance arrangements is the involvement of external experts - yet to a variable extent. In the making of the most integrated spatial energy plan of Berne, for example, a rather broad pool of different experts on energy supply, spatial planning, communication processes, visualization, and data modelling have made significant contributions (Stadt Bern, 2012, pp. 3f.). In the sectorial energy planning of Winterthur, primarily experts like energy engineers and planners were involved (IP 7). This involvement of experts can be interpreted in terms of an active uncertainty management that aims at reducing uncertainty by producing additional knowledge and thereby closing a knowledge gap. Such a strategy was chosen mainly to address technological and economic uncertainties (e.g., biogas potential and geothermal energy sources). 
Besides involving experts, the process of making spatial energy plans featured intense communication and cooperation with political decision-makers (e.g., the municipal parliament, agents of the executive) from almost all administrative departments and public enterprises. In the case of Berne's holistic energy planning arrangement, even a public participation process has been established to accompany the development of the plan, although usually the public is only asked to participate in later planning steps (Stadt Bern, 2012, p. 3). This effort to shift uncertainties to political decision-making and public debate may be qualified as form of copingoriented delegation that shifts responsibility for action to another (more capable or legitimate) decision-making body. However, it could also be an expression of active uncertainty management that aims at reshaping an existing state of uncertainty by means of collective decisions. This just illustrates that the motivation for different strategies in practice is more complex than the theoretical categories suggest.

Some local energy plans remain unspecific when it comes to the definition of goals or measures to implement a certain goal. Rather than setting definite targets and measures, the plans stay flexible to be able to react to future developments while postponing definite decisions that may allow deep transformation processes of the local infrastructure. In Winterthur, for example, the new small district heating systems currently running on a wood basis were designed in a way that they can deliver a similar amount of energy also on a lower temperature level. Such a "flexible" system allows for future conversion to other energy sources, if wood burning becomes out of date once (IP7).

Such an approach of postponing decisions can be classified as a strategy of passive coping by means of delegating decisions to the future. Yet, when it involves preserving resources for future activities, it can also be interpreted as an active adaptation strategy that is directed at achieving resilience. This example illustrates that the empirical qualification in some respects depends on additional information to be gathered from other sources.

Other local energy plans define very concrete targets and measures, e.g., by deciding to build new technological infrastructure systems or to rebuild existing ones in spite of acknowledged uncertainties regarding future technological developments. In Berne, for example, the political goal is to dismantle the gas grid and abandon gas-fired stand-alone systems in the long-term. To reach this goal, the transformation of the heating infrastructure is initiated and pushed now-even though the experts acknowledge that there are many uncertainties and open questions with regard to technological development and the availability, "which can't be answered today". However, in order to initiate a "rebuild" and not just a "conversion", decisions have to be made anyway (IP 2). This strategy entails the possibility that a once-adopted solution might turn out to be suboptimal in the future (in view of technological developments that had not been foreseen). Yet, it can be qualified as an active management of uncertainty since it involves a reshaping of the existing technological landscape/material infrastructure, and thereby the grounds on which a certain situation had been described as uncertain.

A closer look at the substantial decisions made on future urban heat supply in light of uncertainties reveals that specific technological infrastructures, namely district heating and especially small heating networks, are the prioritized solutions (e.g. Winterthur; Pratteln; Schaffhausen). In practice, actors justify these solutions by referring to their flexibility with regard to both the use of various heat sources (an argument that applies especially to urban areas where integration of renewable energy sources in heat supply is difficult) and of temperature levels to react to changes in demand. District heating and small heating networks can be fed by different energy resources, using different transformation technologies. Such a distribution structure provides the potential to either grow to a central system or to remain in decentralized heat islands, depending on what might be most reasonable and sustainable in the future and most appropriate with regard to urban development. Going back to the typology of uncertainty strategies, these decisions toward flexible technical infrastructures can be interpreted as efforts to actively create adaptive capacities to deal with uncertainties in terms of resilience.

\subsection{Dealing with Uncertainties in Different Governance Arrangements}

As mentioned before, the three more deeply analyzed empirical cases differ with regard to their overall governance arrangements. Winterthur and Berne address future urban heat supply in an overreaching strategic planning instrument, with a more holistic approach in the case of Berne and a more sectorial design in the case of Winterthur. In contrast, Basel considers future heat supply in a project-oriented, incremental way.

In examining how uncertainty is dealt with under these different conditions, one might conclude that the more holistic or comprehensive a planning scheme, the higher the probability that uncertainties are addressed and dealt with as an important topic. Strategically oriented arrangements like sectorial or more holistic spatial planning seem to support the identification of uncertainties and the specification of individual strategies for dealing with them. In the two cases of Berne and Winterthur, which dispose of some strategic planning instruments (either holistic or sectorial), the official planning documents address uncertainties with regard to future resource availability and development of consumption. In the more holistic planning arrangement of Berne, uncertainty concerning the future energy sources for heating purposes is discussed in more detail than in Winterthur's sectorial energy plan. The case of Berne, with its holistic planning scheme, shows that the range of identified uncertainties and the variety of strategies to deal 
with them is even higher than in Winterthur's sector planning arrangement.

In Basel, which adopts an incremental approach, it is apparent that, due to the absence of an overall spatial plan and a process of consolidation, uncertainty is not an explicit topic in local energy decisions related to heat supply. The likelihood of neglecting uncertainty in a projectoriented, incremental context seems higher than in the cases with more strategic orientation. Some sources of uncertainty only become obvious within the overall picture created by a governance arrangement that involves planning, while an incremental project view (like in Basel) is less prone to capture a situation's complexity and to identify related uncertainties.

However, three important qualifications need to be made. First, the existence of spatial energy plans does not guarantee that uncertainties are reflected at all. In fact, our broader sample of cases also includes energy plans where uncertainty is not mentioned (e.g. Schlieren; Farvagny). Second, strategic planning does not imply a comprehensive coverage of uncertainties. The two analyzed arrangements with a more strategic orientation (Winterthur and Berne), for example, do not integrate their reflections on uncertainties into a broader context relating to technological and economic conditions and developments or being influenced by societal aspects and users' behaviour. Third, there seems to be an important informal sphere where uncertainties are perceived and dealt with. In fact, all analyzed cases show that uncertainties are reflected by the experts more comprehensively than in the official planning documents. Even in the case of Basel, interviews with experts reveal that uncertainties related to technological developments, the consumers' future demands (e.g., for electro mobility) and ongoing political discussions do play a role in planning and investment decisions of the municipal supply company (IP 6). In fact, in the case of Basel, these uncertainties and the absence of a strategic planning arrangement have created a situation where the supply company plans for two alternative systems-one based on the existing gas grid and one under the conditions of a dismantled grid (IP 4 \& 5).

In all arrangements the inclusion of experts seems to be not only a way to identify uncertainties but also an important strategy to deal with them. Interestingly, such a strategy of active management to reduce uncertainties by filling knowledge gaps also plays a role in the incremental arrangement of Basel. Here, the department responsible for energy affairs commissioned the expert study "Basel on the way to a 2000-watt-society" to address the many interdependencies and uncertainties resulting from the political decision to shift to a renewables-based energy supply (IP 4). The strategy to involve external experts at this point can be interpreted as a strategy to gain knowledge and reduce uncertainty as far as possible. However, in the case of Basel, these efforts are not resulting in commonly defined planning documents and decisions to transform the existing infras- tructure, as is observable in the two cases with a sectorial or holistic planning approach.

Apart from the identified similarities and differences among different governance arrangements, the three cases that we have looked at in more detail suggest that there might be a correspondence between types of uncertainty and strategies for dealing with them. Uncertainties regarding technological development and resource availability are mainly handled in terms of active management-be it by a strategy of reduction that involves experts to close knowledge gaps, or by some form of self-adaptation or resilience strategy that aims at creating an open adaptable structure by deciding for a flexible technology in terms of district heating systems which are open for different energy sources, but create new path dependencies to the same time (Magnusson, 2012).

While technological uncertainties are managed in an active manner, societal and political sources of uncertainty, like changes in users' behaviour and political or legal dynamics are handled, if at all, by passive coping. Actively managing these uncertainties, e.g., by including experts, seems to be an ineffective strategy. One might speculate that there aren't experts on these topics around or that the relevant experts are not included in the planning and decision-making processes that are dominated by natural scientists and technicians. Therefore, one also has to acknowledge the limitations of existing spatial planning instruments for dealing with uncertainty. In their given forms, they might not be sufficiently prepared to face the complexity that arises from the interdependencies among different energy uses and sectors and the dynamics of technological development and norm setting of energy policy. These kinds of complex webs of uncertainties can be neither identified nor solved by local spatial energy plans in their given form.

Finally, and expanding the perspective from planning to implementation, one may speculate whether and how certain strategies for dealing with uncertainties defined in energy plans might have repercussions on the implementation of these plans, creating an additional layer of uncertainties. For example, rebuilding gas grids, as planned in the holistic case of Berne, might be an adequate strategy of adaptation to technological uncertainties. However, the implementation of such a highly invasive strategy can also come with a number of follow-up uncertainties in the societal and political domain, such as unpredictable opposition and protest against the rebuilding of a socially well-entrenched energy infrastructure.

\section{Conclusions and Perspectives}

Uncertainty is widely regarded as one of the most pressing challenges of sustainability governance in theory and practice. This is particularly true for the governance of complex energy systems. With our paper, we have added to the debate on the governance of energy-related uncertainty in three respects. First, we related general conceptual understandings of uncertainty to complex energy 
systems. The proposed "spheres of energy-related uncertainties" provide a comprehensive framework for thinking about and detecting uncertainties related to energy transitions. In particular, this allows for scrutinizing the links between the physical components and the social organization of the energy system and thus widens the analysis beyond a focus simply on technology. Second, we provided a differentiated conceptual framework regarding the ways uncertainties are dealt with by policymakers and planners on the ground. By identifying various ideal typical strategic postures, we have highlighted strategic options underneath the (meso-)level of aggregate governance strategies, such as planning, incrementalism and directed incrementalism. The framework can serve to empirically illuminate and interpret individual decisions with regard to uncertainty and disentangle the prevailing aggregated view on uncertainty governance. Third, our empirical analysis of urban heat supply policies in Switzerland shows that our conceptual investments are suitable to detect representations of uncertainty and ways uncertainties are dealt with on the ground. On this conceptual level lies the main potential for generalizing our observations: we have good reasons to believe that our frameworks capture relevant empirical phenomena and thereby have the potential to illuminate uncertainties and ways of dealing with them in different contexts.

Aside from this validation of the usefulness of our conceptual considerations, it is possible to draw some preliminary empirical conclusions regarding the microgovernance of uncertainty. We would like to highlight four general aspects, which can be expected to "travel" beyond the Swiss context. First, it seems to be the case that different governance schemes allow for the consideration of uncertainties. In fact, uncertainties do play a role in all types of arrangements-ranging from planning to incrementalism. Yet this does not mean that every single case takes account of uncertainty-not even all cases with holistic spatial energy plans. Put differently, given that there are also energy plans where uncertainty is not addressed at all, there is no guarantee that, under any conditions, uncertainties do come into view, not even within holistic planning schemes. The particular (in-)sensitivity towards uncertainties is not explained by the existence (absence) of an energy plan. Second, it can be concluded that some kinds of uncertainties are more salient than others. Technological and economic uncertainties tend to be more prevalent than societal and political uncertainties. Put differently, there is a tendency to take account of technological and economic uncertainties while neglecting others. Some dimensions of uncertainty, e.g., the complexity related to interdependencies between the different energy uses and sectors and the dynamics of technological development and energy policy, are not reflected in the analyzed documents. Whether or not this holds true for different governance schemes remains an open empirical question. Third, concerning strategies for dealing with uncertainties, we have not found evidence that all kinds of ideal typical strate- gies do in fact play a role. There is a proclivity towards strategies of technological reshaping to deal with uncertainties. Investing in and bringing out "flexible technologies" is a rather dominant strategy to deal with uncertainty. Another dominant strategy consists in reducing uncertainties via the production of knowledge and expertise. Including experts is a prioritized strategy when it comes to dealing with technological aspects, resource availability, and development of demand. Furthermore, there is a tendency to delegate actions regarding uncertainties from the local to the cantonal or federal level. Fourth, some forms of uncertainty, i.e., the societal and political ones, seem to be addressed by means of passive coping rather than active management. In other words, uncertainties such as changes in users' behaviour as well as dynamics in political and legal settings, etc., seem to lie outside the action realm of local policymakers and planners. As there is no clear evidence that the various governance arrangements differ in that respect, the neglect of societal and political uncertainties might turn out to be a more fundamental tendency in the practice of energy-related policymaking and planning.

Based on the proposed conceptual frameworks and our preliminary empirical findings, we suggest the following routes for future research. First, more empirical studies in various political administrative contexts (and at various policy levels) can further substantiate and enrich the empirical picture regarding the perception and representation of uncertainty and ways of dealing with it. More particularly, comparative research might reveal more general patterns of uncertainty representation and how these patterns are related to different strategies for dealing with uncertainties (see also Arentsen et al., 2000). Furthermore, more empirical studies will have to further explore the link between overall governance arrangements, such as planning, incrementalism, and directed incrementalism, the representation of uncertainties within these schemes, and more specific strategies for dealing with different kinds of uncertainties. Longitudinal empirical analyses might also reveal the dynamics within the governance of uncertainty: the evolution of understandings of uncertainties and practices for dealing with them over time. Drawing on these reconstructions of empirical patterns, one could attempt to develop more robust explanatory approaches. Under which conditions do which forms of uncertainty emerge? And what factors and conditions explain the various ways uncertainties are dealt with? Furthermore, additional empirical analysis on the success and failure of strategies to deal with uncertainties can be carried out. This kind of analysis would require the development of sophisticated evaluative criteria to assess the performance of uncertainty strategies. Finally, in practical respects, these kinds of analysis might inform policymakers and planners about "working" strategies for dealing with uncertainty: What works when and where in order to deal with what kind of uncertainty? And they might support governance designers in their efforts to set up governance arrange- 
ments that allow policymakers and planners to develop tailor-made strategies for dealing with different kinds of uncertainties in a reflexive manner.

\section{Acknowledgments}

The authors are indebted to the editors of the special issue for taking the paper on board as well as two anonymous reviewers, whose comments helped to significantly improve the paper. The authors would also like to thank Paul Burger and the Sustainability Research Group, University of Basel, for helpful comments on an earlier version of the paper.

\section{Conflict of Interests}

The authors declare no conflict of interests.

\section{References}

Akademien der Wissenschaften Schweiz (Swiss Academies of Arts and Sciences). (2012). Zukunft Stromversorgung Schweiz. Bern: Akademien der Wissenschaften Schweiz.

Araújo, K. (2014). The emerging field of energy transitions: Progress, challenges, and opportunities. Energy Research \& Social Science, 1, 112-121. doi:10.10 16/j.erss.2014.03.002

Arentsen, M. J., Bressers, H. T., \& O’Toole, L. J. (2000). Institutional and policy responses to uncertainty in environmental policy: A comparison of Dutch and U.S. styles. Policy Studies Journal, 28(3), 597-611. doi:10.1111/j.1541-0072.2000.tb02050.x

Bammer, G., \& Smithson, M. (Eds.). (2008). Uncertainty and risk: Multidisciplinary perspectives. London: Earthscan.

Bammer, G., Smithson, M., \& Goolabri Group. (2008). Coping and managing under uncertainty. In G. Bammer \& M. Smithson (Eds.), Uncertainty and risk: Multidisciplinary perspectives (pp. 321-333). London: Earthscan.

Beck, U. (2006). Reflexive governance: Politics in the global risk society. In J.-P. Voss, D. Bauknecht, \& R. Kemp (Eds.), Reflexive governance for sustainable development (pp. 31-56). Cheltenham, UK: Edward Elgar.

Berkes, F. (2007). Understanding uncertainty and reducing vulnerability: Lessons from resilience thinking. Natural Hazards, 41(2), 283-295. doi:10.1007/ s11069-006-9036-7

BMWI (German Federal Ministry for Economic Affairs and Energy), \& BMU (German Federal Ministry for the Environment, Nature Conservation and Nuclear Safety). (2010). Energiekonzept für eine umweltschonende, zuverlässige und bezahlbare Energieversorgung. Berlin.

Braybrooke, D., \& Lindblom, C. E. (1963). A strategy of decision. Policy evaluation as a social process. New York: The Free Press.
Bressers, H. T. A. (1997). Institutional and policy responses to uncertainty in environmental policy. In L. Mez \& H. Weidner (Eds.), Umweltpolitik und Staatsversagen. Perspektiven und Grenzen der Umweltpolitikanalyse; Festschrift für Martin Jänicke zum 60. Geburtstag (pp. 288-296). Berlin: Edition Sigma.

Brugnach, M., Dewulf, A., Pahl-Wostl, C., \& Taillieu, T. (2008). Toward a relational concept of uncertainty: About knowing too little, knowing too differently, and accepting not to know. Ecology and Society, 13(2), 30.

Byrne, R. M. J. (2005). The rational imagination: How people create alternatives to reality. Cambridge, MA: MIT Press.

Camhis, M. (1979). Planning theory and philosophy. London and New York: Tavistock Publications.

Christensen, K. S. (1985). Coping with uncertainty in planning. Journal of the American Planning Association, 51(1), 63-73. doi:10.1080/01944368508976801

Courtney, H., Kirkland, J., \& Viguerie, P. (1997). Strategy under uncertainty. Harvard Business Review, 75(6), 67-79.

DENA (Deutsche Energie-Agentur). (2010). Biomethan im KWK- und Wärmemarkt. Status Quo, Potenziale und Handlungsempfehlungen für eine beschleunigte Marktdurchdringung. Berlin: Deutsche EnergieAgentur.

DLR (Deutsches Zentrum für Luft- und Raumfahrt), IWES (Fraunhofer Institut für Windenergie und Energiesystemtechnik), \& IFNE (Ingenieurbüro für neue Energien). (2012). Langfristszenarien und Strategien für den Ausbau der erneuerbaren Energien in Deutschland bei Berücksichtigung der Entwicklung in Europa und global. Schlussbericht BMU - FKZ 03MAP146. Berlin.

Enserink, B., Kwakkel, J. H., \& Veenman, S. (2013). Coping with uncertainty in climate policy making: (Mis)understanding scenario studies. Futures, 53, 112. doi:10.1016/j.futures.2013.09.006

Everett, B., Boyle, G., Peake, S., \& Ramage, J. (Eds.). (2012). Energy systems and sustainability: Power for a sustainable future. Oxford: Oxford University Press.

Goldthau, A. (2014). Rethinking the governance of energy infrastructure: Scale, decentralization and polycentrism. Energy Research \& Social Science, 1, 134140. doi:10.1016/j.erss.2014.02.009

Gottschick, M. (2014). How stakeholders handle uncertainty in a local climate adaptation governance network. Climatic Change, 123(3), 1-13. doi:10.1007/ s10584-014-1203-3

Gross, M. (2007). The unknown in process: Dynamic connections of ignorance, non-knowledge and related concepts. Current Sociology, 55(5), 742-759. doi:10.1177/0011392107079928

Gross, M. (2010). Ignorance and surprise: Science, society, and ecological design. Cambridge, MA: MIT Press.

Grunwald, A. (2000). Technology policy between longterm planning requirements and short-ranged accep- 
tance problems. In J. Grin \& A. Grunwald (Eds.), Vision assessment: Shaping technology in 21st century society (pp. 99-147). Berlin and Heidelberg: Springer.

Grunwald, A. (2007). Working towards sustainable development in the face of uncertainty and incomplete knowledge. Journal of Environmental Policy \& Planning, 9(3), 245-262. doi:10.1080/152390 80701622774

Guy, S., \& Shove, E. (2000). A sociology of energy, buildings, and the environment: Constructing knowledge, designing practice. London and New York: Routledge.

Hajer, M. (2003). Policy without polity? Policy analysis and the institutional void. Policy Sciences, 36(2), 175195.

Jänicke, M., \& Jörgens, H. (1999). National environmental policy planning in the face of uncertainty. In $\mathrm{M}$. Kenny \& J. Meadowcroft (Eds.), Environmental politics. Planning sustainability (pp. 175-198). London and New York: Routledge.

Jeschke, S., Jakobs, E.-M., \& Dröge, A. (Eds.). (2013). Exploring uncertainty: Ungewissheit und Unsicherheit im interdisziplinären Diskurs. Wiesbaden: Springer Gabler.

Kanton Basel-Stadt. (2013). Basel auf dem Weg zur 2000 Watt-Gesellschaft. Basel: Department für Wirtschaft, Soziales und Umwelt, Amt für Umwelt und Energie.

Kaufmann, S., \& Blum, S. (2012). Governing (in)security: The rise of resilience. In H.-H. Gander, W. Perron, R. Poscher, G. Riescher, \& T. Würtenberger (Eds.), Sicherheit und Gesellschaft: Resilienz in der offenen Gesellschaft. Symposium des Centre for Security and Society (pp. 235-257). Baden-Baden: Nomos.

Kemp, R., \& Loorbach, D. (2006). Transition management: A reflexive governance approach. In J.-P. Voss, D. Bauknecht, \& R. Kemp (Eds.), Reflexive governance for sustainable development (pp. 103-130). Cheltenham, UK: Edward Elgar. Kern, F., \& Smith, A. (2008). Restructuring energy systems for sustainability? Energy transition policy in the Netherlands. Energy Policy, 36(11), 4093-4103. doi:10.1016/ j.enpol.2008.06.018

Kuzemko, C., Lockwood, M., Mitchell, C., \& Hoggett, R. (2016). Governing for sustainable energy system change: Politics, contexts and contingency. Energy Research \& Social Science, 12, 96-105. doi:10.1016/ j.erss.2015.12.022

Laes, E., Gorissen, L., \& Nevens, F. (2014). A comparison of energy transition governance in Germany, The Netherlands and the United Kingdom. Sustainability, 6(3), 1129-1152.

Lindblom, C. E. (1969). The science of "muddling through". In A. Etzioni (Ed.), Readings on modern organizations. Englewood Cliffs, NJ: Prentice Hall.

Lindblom, C. E. (1973). Incrementalism and environmentalism. In A. Neuschatz (Ed.), Managing the Environment (pp. 83-84). Washington, DC: Environmental Protection Agency.

Lindblom, C. E. (1999). A century of planning. In M.
Kenny \& J. Meadowcroft (Eds.), Environmental politics. Planning sustainability (pp. 39-65). London and New York: Routledge.

Longstaff, P. H. (2012). Complexity and resilience: Concepts of community security. In H.-H. Gander, W. Perron, R. Poscher, G. Riescher, \& T. Würtenberger (Eds.), Sicherheit und Gesellschaft: Resilienz in der offenen Gesellschaft. Symposium des Centre for Security and Society (pp. 259-281). Baden-Baden: Nomos.

Magnusson, D. (2012). Swedish district heating-A system in stagnation: Current and future trends in the district heating sector. Energy Policy, 48, 449-459. doi:10.1016/j.enpol.2012.05.047

Mazouz, N. (2003). Unsicherheit der Normativität und Normativität der Unsicherheit in den Diskursfeldern "globaler Wandel" und "Nachhaltigkeit". In N. Gottschalk-Mazouz \& N. Mazouz (Eds.), NachhaItigkeit und globaler Wandel. Integrative Forschung zwischen Normativität und Unsicherheit (pp. 203256). Frankfurt a.M. and New York: Campus.

Meadowcroft, J. (1999). Planning for sustainable development: What can be learned from the critics? In M. Kenny \& J. Meadowcroft (Eds.), Environmental politics. Planning sustainability (pp. 12-38). London, New York: Routledge.

Meadowcroft, J. (2009). What about the politics? Sustainable development, transition management, and long term energy transitions. Policy Sciences, 42(4), 323340. doi:10.1007/s11077-009-9097-z

Meijer, I., \& Hekkert, M. P. (2007). Managing uncertainties in the transition towards sustainability: Cases of emerging energy technologies in the Netherlands. Journal of Environmental Policy \& Planning, 9(3), 281-298. doi:10.1080/15239080701622865

Milliken, F. J. (1987). Three types of perceived uncertainty about the environment: State, effect, and response uncertainty. The Academy of Management Review, 12(1), 133-143. doi:10.2307/257999

Monstadt, J. (2004). Die Modernisierung der Stromversorgung: Regionale Energie- und Klimapolitik im Liberalisierungs- und Privatisierungsprozess. Wiesbaden: VS Verlag für Sozialwissenschaften.

Monstadt, J. (2009). Conceptualizing the political ecology of urban infrastructures: Insights from technology and urban studies. Environment and Planning $A$, 41(8), 1924-1942. doi:10.1068/a4145

Moore, M. (2008). Political practice: Uncertainty, ethics and outcomes. In G. Bammer \& M. Smithson (Eds.), Uncertainty and risk. Multidisciplinary perspectives (pp. 171-182). London: Earthscan.

Morgan, M. G., Henrion, M., \& Small, M. (1990). Uncertainty: A guide to dealing with uncertainty in quantitative risk and policy analysis. Cambridge and New York: Cambridge University Press.

Polasky, S., Carpenter, S. R., Folke, C., \& Keeler, B. (2011). Decision-making under great uncertainty: Environmental management in an era of global 
change. Trends in Ecology \& Evolution, 26(8), 398404. doi:10.1016/j.tree.2011.04.007

Raven, R. (2007). Niche accumulation and hybridisation strategies in transition processes towards a sustainable energy system: An assessment of differences and pitfalls. Energy Policy, 35(4), 2390-2400. doi:10.1016/j.enpol.2006.09.003

Renn, O. (2008). Risk governance: Coping with uncertainty in a complex world. London: Earthscan.

Schimank, U. (2005). Die Entscheidungsgesellschaft. Komplexität und Rationalität der Moderne. Hagener Studientexte zur Soziologie. Wiesbaden: VS Verlag für Sozialwissenschaften.

Schippl, J., Grunwald, A., \& Renn, O. (2012). Future infrastructures for meeting energy demands. GAIAEcological Perspectives for Science and Society, 21(3), 242-243.

Schubert, S. (2015). Die Rolle räumlicher Planung zur Förderung klimaschonender Wärme- und Kälteversorgung in Deutschland und der Schweiz. Lemgo: Rohn.

Smithson, M. (1989). Ignorance and uncertainty: Emerging paradigms. Cognitive science. New York: Springer.

Smithson, M. (2008). The many faces and masks of uncertainty. In G. Bammer \& M. Smithson (Eds.), Uncertainty and risk. Multidisciplinary perspectives (pp. 13-25). London: Earthscan.

Solomon, B. D., \& Krishna, K. (2011). The coming sustainable energy transition: History, strategies, and outlook. Energy Policy, 39(11), 7422-7431. doi:10.1016/ j.enpol.2011.09.009

Stadt Aarau (2012). Kommunaler Energieplan der Stadt Aarau. Aarau: Stadt Aarau.

Stadt Bern (2012). Richtplan Energie der Stadt Bern. Bern: Stadt Bern.

Stadt Wädenswil. (2009). Kommunaler Energieplan der Stadt Wädenswil. Wädenswil: Stadt Wädenswil.

Stadt Winterthur. (2011). Kommunaler Energieplan Winterthur. Winterthur: Stadt Winterthur.

Stadt Winterthur, Umwelt- und Gesundheitsschutz. (2011). Grundlagen Energiekonzept 2050. Winterthur: Stadt Winterthur.

Steurer, R., \& Martinuzzi, A. (2005). Towards a new pattern of strategy formation in the public sector: First experiences with national strategies for sus- tainable development in Europe. Environment and Planning C: Government and Policy, 23(3), 455-472. doi:10.1068/c0403j

Stirling, A. (2014). Transforming power: Social science and the politics of energy choices. Energy Research \& Social Science, 1, 83-95. doi:10.1016/ j.erss.2014.02.001

Tversky, A., \& Kahneman, D. (1974). Judgment under uncertainty: Heuristics and biases. Science, 185(4157), 1124-1131. doi:10.1126/science.185.4157.1124

UBA (Federal Environment Agency, Germany). (2007). Potenziale von Nah- und Fernwärmenetzen für den Klimaschutz bis zum Jahr 2020. Dessau-Rosslau: UBA.

van Asselt, M. B. A., \& Rotmans, J. (2002). Uncertainty in integrated assessment modelling. Climatic Change, 54(1-2), 75-105. doi:10.1023/A:1015783803445

Verbong, G., \& Geels, F. (2007). The ongoing energy transition: Lessons from a socio-technical, multilevel analysis of the Dutch electricity system (19602004). Energy Policy, 35(2), 1025-1037. doi:10.1016/ j.enpol.2006.02.010

Voss, J.-P., Newig, J., Kastens, B., Monstadt, J., \& Nölting, B. (2007). Steering for sustainable development: A typology of problems and strategies with respect to ambivalence, uncertainty and distributed power. Journal of Environmental Policy \& Planning, 9(3), 193212. doi:10.1080/15239080701622881

Walker, W. E., Harremoës, P., Rotmans, J., van der Sluijs, J. P., van Asselt, M. B. A., Janssen, P., \& Krayer von Krauss, M. P. (2003). Defining uncertainty: A conceptual basis for uncertainty management in modelbased decision support. Integrated Assessment, 4(1), 5-17. doi:10.1076/iaij.4.1.5.16466

Weick, K. E., \& Sutcliffe, K. M. (2015). Managing the unexpected: Sustained performance in a complex world. Hoboken, New Jersey:

Wiley. Wuppertal Institut für Klima, Umwelt, Energie. (2010). Erdgas: Die Brücke ins regenerative Zeitalter. Bewertung des Energieträgers Erdgas und seiner Importabhängigkeit. Hintergrundbericht im Auftrag der Greenpeace Deutschland. Wuppertal: Wuppertal Institut für Klima, Umwelt, Energie.

Willke, H. (2014). Demokratie in Zeiten der Konfusion. Berlin: Suhrkamp.

\section{About the Authors}

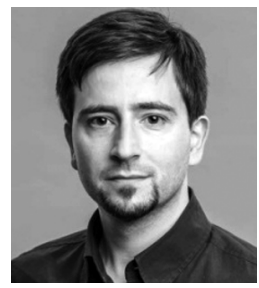

Basil Bornemann has an interdisciplinary study background in environmental sciences and holds a doctoral degree in political science from Leuphana University of Lueneburg, Germany. Following his overall interest in societal transformations toward sustainability, he has extensively studied policy integration in the context of sustainable development strategies. Basil's current research at the Sustainability Research Group, University of Basel, Switzerland, focuses on the relationship between governance, sustainable development and democracy within various fields, such as energy and food policy. 


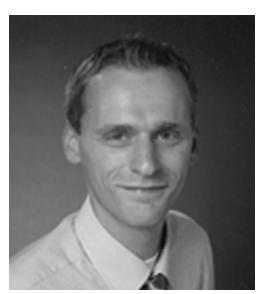

Stephan Schmidt has studied human geography at the University of Greifswald, Germany, and holds a doctoral degree in sustainability research from the University of Basel, Switzerland. During his postdoc at the Research Center for Sustainable Energy and Water Management, University of Basel, he investigated the governance of a sustainable energy transition as well as socio-economic conditions of the energy system transformation. In his current position as managing director of the Upper Rhine Cluster for Sustainability Research, Stephan facilitates research cooperation and science communication.

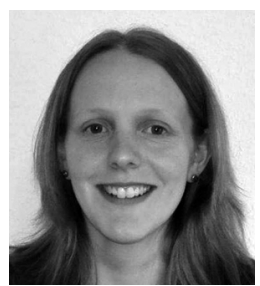

Susanne Schubert has studied urban planning at the HafenCity University of Hamburg, Germany, and holds a doctoral degree in civil engineering from the Technical University of Darmstadt, Germany. Her research focus is on the interface of sectoral infrastructure planning and overall spatial planning, on sustainable solutions for urban heat supply and their development in urban energy regimes. She is further interested in planning instruments and their relevance for environmental protection. Currently Susanne is working for the German Environment Agency in the section for sustainable spatial development and environmental assessment on urban environmental management. 


\section{Annexes}

\section{Empirical Data}

Table A1. Planning and policy documents.

\begin{tabular}{|c|c|}
\hline Case & Document(s) \\
\hline Aarau & Stadt Aarau (2012). Kommunaler Energieplan der Stadt Aarau. Aarau. \\
\hline Arlesheim & Gemeinde Arlesheim (2009). Energiesachplan Arlesheim. Arlesheim. \\
\hline Basel & $\begin{array}{l}\text { Kanton Basel-Stadt, Bau- und Verkehrsdepartement (2009). Kantonaler Richtplan. Basel. } \\
\text { Kanton Basel-Stadt (2013). Basel auf dem Weg zur } 2000 \text { Watt-Gesellschaft. Basel: Department für } \\
\text { Wirtschaft, Soziales und Umwelt, Amt für Umwelt und Energie. }\end{array}$ \\
\hline Berne & $\begin{array}{l}\text { Stadt Bern (2006). Energiestrategie der Stadt Bern 2006-2015. Bern. } \\
\text { Stadt Bern, Direktion für Sicherheit, Umwelt und Energie (2012). Richtplan Energie der Stadt Bern. }\end{array}$ \\
\hline Boedeli & $\begin{array}{l}\text { Gemeinden Bönigen, Interlaken, Matten, Unterseen, \& Wilderswil (2011). Überkommunaler Richtplan } \\
\text { Energie "Bödeli", Erläuternder Bericht mit verbindlichem Richtplantext und Massnahmenblättern. } \\
\text { Bönigen, Interlaken, Matten, Unterseen, Wilderswil. }\end{array}$ \\
\hline Bulle & Ville de Bulle (2001). Plan communal des énergies. Bulle. \\
\hline Farvagny & Commune de Farvagny (2011). Le plan communal des énergies. Farvagny. \\
\hline Geneva & Ville de Génève (2009). Politique énergétique et climatique de la Ville de Genève. Genève. \\
\hline Kloten & Stadt Kloten (2008). Kommunaler Energieplan der Stadt Kloten. Kloten. \\
\hline La Brillaz & Commune de La Brillaz (2011). Plan communal des énergies. La Brillaz. \\
\hline Pratteln & Gemeinde Pratteln (2011). Energiesachplan Pratteln. Pratteln. \\
\hline Schaffhausen & Stadt Schaffhausen (2007). Energierichtplan Stadt Schaffhausen. Schaffhausen. \\
\hline Schlieren & Stadt Schlieren (2012). Kommunaler Energieplan der Stadt Schlieren. Schlieren. \\
\hline Thun & $\begin{array}{l}\text { Gemeinden Heimberg, Steffisburg, Uetendorf und Stadt Thun (2010). Überkommunaler Richtplan } \\
\text { Energie. Heimberg, Steffisburg, Uetendorf, Thun. }\end{array}$ \\
\hline Wädenswil & Stadt Wädenswil (2009). Kommunaler Energieplan der Stadt Wädenswil. Wädenswil. \\
\hline Winterthur & $\begin{array}{l}\text { Stadt Winterthur, Umwelt- und Gesundheitsschutz (2011). Grundlagen Energiekonzept 2050. Winterthur } \\
\text { Stadt Winterthur (2011): Kommunaler Energieplan Winterthur. Winterthur. }\end{array}$ \\
\hline
\end{tabular}

Table A2. Interviews.

\begin{tabular}{lll}
\hline Number & Institution & Date and Place \\
\hline IP 1 & $\begin{array}{l}\text { Head of the Divison “Energy and Technology", Departement of Building } \\
\text { and Construction, City of Winterthur }\end{array}$ & 18.04 .2013$, Winterthur \\
IP 2 & Head of the Division “Environment and Energy", City of Berne & 07.05 .2013$, Berne \\
IP 3 & Head of the Divison “Energy Services", Energy Water Berne (EWB) & 21.05 .2013$, Berne \\
IP 4 & Head of the Division “Energy", Office of Environment and Energy, City of Basel & 24.04 .2013$, Basel \\
IP 5 & Staff member of the Divison “District Heating", Industrial Plants Basel (IWB) & 15.05 .2013$, Basel \\
IP 6 & Head of the Divison "Strategy and Cooperation", Industrial Plants Basel (IWB) & 15.05 .2013$, Basel \\
IP 7 & Head of the Division “Energy Contracting", Municipal Utilities Winterthur & 26.06 .2013$, Winterthur \\
\hline
\end{tabular}

